\title{
Currency War or International Policy Coordination?
}

\author{
Barry Eichengreen \\ University of California, Berkeley
}

January 2013

\section{Introduction}

"Currency war" is a meme that will not go away. The term was coined by Brazilian finance Minister Guido Mantega in September 2010 in response to quantitative easing in the United States. Mantega's implied criticism was that the unconventional monetary policies of the Federal Reserve to ward off deflation and stimulate a depressed economy were beggar thy neighbor. They unleashed a tsunami of capital flows toward emerging markets, resulting in inflation, currency appreciation, loss of competitiveness and worrisome upward pressure on asset prices. Brazilian president Dilma Rousseff invoked the term and echoed her finance minister's criticism in the spring of 2012 and again on a visit to the White House later in the year. At the end of 2012 and beginning of 2013, when Bank of Japan committed to large-scale asset purchases and the government of newly elected Prime Minister Shinzo Abe looked to raise the central bank's inflation target, once more there were accusations, this time mainly from Japan's Asian neighbors, that the country was waging a clandestine currency war. ${ }^{1}$

What implications for policy flow from these complaints? A first possible implication, which Brazilian leaders presumably have in mind, is that these unconventional monetary policies are ineffective for achieving their goal of accelerating recovery and growth in the advanced economies but have negative spillover effects on emerging markets and should therefore be abandoned. A second interpretation, with significantly different implications, is that unconventional monetary policies have both positive impacts on the advanced countries and negative impacts on other countries feeling their spillover effects. In this case it is no longer clear that the first-best response is for countries like the United States to abandon their unconventional policies. Rather the optimal response may simply be for other countries to adjust their own policies to neutralize any adverse spillover effects.

But the circumstances under which countries acting unilaterally can achieve the first-best global equilibrium are restrictive. This point is well known courtesy of the now large literature on international policy coordination (Hamada 1976, Cooper 1984, Meyer, Doyle, Gagnon and Henderson 2002). If other distortions are present, non-pecuniary spillovers result, and countries are individually or collectively large enough for their policies to affect one another, then unilateral actions and reactions may not yield the optimal outcome. International cooperation - an internationally coordinated mutual adjustment of policies - can in this case yield a pareto superior result. There is then the further question of whether the gains from international coordination are large or small, with much of the academic literature pointing in the latter direction.

The current debate has an analogy in the 1930s, when interest rates approached zero, national monetary action was criticized as beggar thy neighbor, and gains from international policy coordination were allegedly left on the table. ${ }^{2}$ The question is whether this conventional rendering is in fact an

\footnotetext{
${ }^{1}$ In January 2013 the first deputy chairman the Central Bank of Russia, Aleksey Ulyukaev, then warned that "We are now on the threshold of a very serious, I think, confrontational action, which is called, maybe excessively emotionally, "currency wars.” http://rt.com/business/news/currency-war-ulyukaev-japan-104/

${ }^{2}$ The Encyclopedia of the World Economy tells us that "Beggar-thy-neighbor policies are those that seek to increase domestic economic welfare at the expense of other countries; welfare. What might be called the classic case of
} 
accurate characterization of what happened in the 1930s and therefore whether the lessons of that experience carry over to today.

\section{The Story Then}

Eichengreen and Sachs $(1985,1986)$ used historical evidence and a two-country MundellFleming model to analyze the domestic and cross-border impacts of monetary and exchange rate policies in the 1930s. In that model the domestic impact of monetary expansion operated through a number of channels. To the extent that it raised real asset prices (Tobin's q), it stimulated investment. To the extent that it stemmed deflation, it limited the increase in debt burdens and the squeeze on profits. By raising expected future inflation, it encouraged households to shift consumption to the present from the future. By leading to real exchange rate depreciation, it stimulated net exports, further increasing the demand for domestic goods.

Cross-country evidence and national case studies alike confirm the existence of significant within-country effects. Countries abandoning the gold standard, depreciating their currencies, and expanding domestic supplies of money and credit recovered more quickly from the Depression than countries following the opposite policies. There is a close correlation between the timing of these policy initiatives and the timing of recovery.

This evidence is of course inconsistent with the view that monetary expansion achieved through conventional or unconventional means is ineffectual under conditions of near-zero interest rates. It is worth considering, therefore, precisely why monetary policy was effective under liquidity-trap-like conditions. The explanation comes in three parts. First, central banks engaged in what we would now call forward guidance. They committed to keeping interest rates low, expanding supplies of money and credit, and raising the domestic currency price of gold for as long as it took for conditions to normalize. Going off the gold standard was the single most important measure signaling this commitment; it was taken as signifying a dramatic permanent change in monetary regime. ${ }^{3}$ In the United States, President Franklin Delano Roosevelt used gold purchases to vanquish expectations of deflation and replace them with what were, under the circumstances, healthy expectations of inflation. In the United Kingdom, the Bank of England committed to keeping interest rates at 2 per cent, in the so-called policy of "cheap money," for as long as it took for normalcy to return. ${ }^{4}$ In Sweden, the government and central bank replaced the gold standard with an explicit price level target. In Japan, the government complemented its reflationary monetary policy with a large increase in public spending that further underscored the new nature of the policy regime. In each of these countries, depreciation against the currencies of countries still on the gold standard was effective for inducing the desired expectations of a higher future price level in the manner of Svensson (2003).

Second, the change in monetary policy had a positive impact on asset prices and therefore on investment. Asset prices reacted immediately to the change in monetary regime. Investment and, with it, industrial production reacted immediately to the change in asset prices. Then, like now, there was

\footnotetext{
beggar-thy-neighbor policies occurs when one country devalues it currency in order to boost its domestic output and employment but, by doing so, shifts the output and employment problem onto other countries. This occurred in the 1930s when, faced with a worldwide recession, countries sought to increase their own output and employment by devaluing their currencies, a policy that would boost domestic output by reducing the demand for imports and increasing the demand for exports. This exacerbated the recession in other countries, however, and invited the response of devaluations by other countries and countries became locked into a series of competitive devaluations." The entry then concludes, "The solution to the use of beggar-thy-neighbor policies in the 1930s was found in the international policy coordination instituted under the auspices of the Bretton Woods system.” http://worldeconomics.org/40-beggar-thy-neighbor-policies.html . As we shall see, conventional wisdom dies hard.

${ }^{3}$ Temin and Wigmore (1990) and Eggertsson (2008) emphasize this expectational channel.

4 This is described in Nevin (1955) and Howson (1975).
} 
criticism of central banks for pushing up asset prices to unsustainable heights - for "blowing bubbles" although it is hard to take this critique seriously given the very low levels to which equity prices, in particular, had fallen. In any case, there is little question that this asset-valuation effect had at least a mild positive impact on investment and output, usefully in a period when investment and output had fallen to disastrously low levels.

Third and most controversial was the real exchange rate effect on competitiveness. Countries abandoning the gold standard and taking steps to depreciate their currencies were able to expand their exports relative to countries remaining on gold. This channel is controversial because the expansion of exports took place at the expense of other countries, worsening the latter's economic difficulties. Reflecting the extent to which this was a two-way street is the fact that virtually none of the countries abandoning the gold standard had succeeded in re-attaining 1929 export volumes by the middle of the 1930s.

If the own-country impact of unconventional monetary policies in the 1930s was unambiguously positive, the overall direction of cross-border spillovers is less clear because of the existence of offsetting effects. The cross-border spillover of the direct real exchange rate effect was negative, as described above. Improved export competitiveness for countries with depreciated exchange rates had as its counterpart worsened export competitiveness for other countries, with the magnitude of this spillover depending on the substitutability of domestic and foreign goods. In contrast, the cross-border spillover of the increase in the level of money and credit was positive. Capital outflows from countries depreciating their currencies, or at least diminution of earlier capital inflows, helped to relax conditions in money and credit markets and moderate expected deflation in other countries, other things equal. ${ }^{5}$ But it is likely that the export-competitiveness effect dominated. Both calibration exercises and the historical literature suggest that the overall spillover was negative.

In circumstances where different countries had all experienced the same deflationary shock, the appropriate foreign response was to meet monetary expansion with monetary expansion and currency depreciation with currency depreciation. Two dozen countries, primarily trade and financial partners of the United Kingdom, responded by depreciating their currencies along with sterling. In other countries, considerations of history, politics and ideology delayed or even precluded recourse to this first-best response. Some countries in this position responded with capital controls and trade restrictions designed to switch demand toward local producers. ${ }^{6}$ This was less efficient than the first-best response both for them and for their foreign partners. ${ }^{7}$

An international coordinated response, it was argued then and has been argued since, would have been better. But given the symmetric deflationary monetary shock from which economies were suffering, the sum of the first-best unilateral responses was also the global optimum. Explicit coordination was not needed to achieve it. With few exceptions, countries had arrived at this set of policies (the depreciation of currencies against gold was all but universal) by the end of 1936 .

For a coordinated response to have been superior, one must add another argument. A plausible argument is that the uncoordinated manner in which currencies were depreciated in the 1930s created uncertainty that demoralized financial market participants, worsening economic conditions. Had there been international agreement to raise the price of gold through, inter alia, simultaneous central bank

\footnotetext{
${ }^{5}$ This effect was not always clear to see, since other things were not equal. Notably, increased political tensions between Germany and its European neighbors led to capital flight toward the United States (Romer 1992).

${ }^{6}$ The linkage is documented in Eichengreen and Irwin (2010).

${ }^{7}$ The distinction between first- and second-best policy responses, where the first-best response is the one targeted most directly at the underlying distortion (in the present case, monetary policy being targeted most directly at monetary deflation) has a long history in the literature going back at least to Bhagwati and Ramaswami (1963).
} 
purchases in all countries, this uncertainty would have been avoided. While there is some evidence that policy uncertainty had negative macroeconomic consequences in the 1930s, there is no evidence that its effects were large. ${ }^{8}$ This is consistent with modern arguments that there are gains from international policy coordination but that they tend to be relatively small.

Moreover, countries unwilling to raise the domestic price of gold unilaterally for historical, political and ideological reasons were equally unwilling to do so as part of an internationally coordinated initiative. The agenda of the World Economic Conference, convened in London in 1933 with the goal of arranging an internationally coordinated policy response to the Great Depression, was to prevent the United States from raising the dollar price of gold, not to get other countries to join it in doing so. International policy coordination was not possible because countries could not agree on policies to coordinate. U.S. President Roosevelt delivered his "bombshell message" to the conference precisely in order to prevent it from limiting his freedom of unilateral action. ${ }^{9}$

\section{The Story Now}

There is less scholarly consensus on the effects of unconventional monetary policies since 2008 in part because that experience is so recent; it has yet to be fully digested. Some studies (e.g. Kapetanios, Mumtaz, Stevens and Theodoridis 2012, Gagnon, Raskin, Remarche and Sack 2011, Swanson 2011) report evidence of positive own-country effects. Others are more skeptical.

Haberis and Lipinska (2012) focus on the cross-border effects. They consider a new Keynesian model of two economies at the zero lower bound. In their model, more expansionary home-country monetary policy worsens the foreign policymaker's tradeoff between stabilizing inflation and the output gap when home and foreign goods are close substitutes. This is because looser home-country policy causes the foreign currency to appreciate, which leads to large shifts in spending away from foreign output when goods produced by the two countries are close substitutes. In contrast, when the goods of the two countries are not close substitutes, the ability of foreign policy makers to stabilize their economy benefits from a more expansionary home-country policy because the expenditure-changing effects dominate the expenditure-switching effects. Note that this analytical result intended to capture the crossborder effects of unconventional monetary policies in the current environment is precisely analogous to the result for the 1930s in Eichengreen and Sachs (1985).

The difference from the 1930s is that the pattern of shocks is more heavily asymmetric in the recent episode. Where the advanced countries were hit by a deflationary shock which, in conjunction with the policy response, moved interest rates to the zero lower bound, emerging markets felt less deflationary pressure, experienced less deleveraging, and maintained healthier growth rates. In their case, inflation rates, asset prices and arguably growth rates were already uncomfortably high. ${ }^{10}$ Only one, not both sets of countries represented in the model, was at the zero lower bound.

The optimal unilateral response by the second set of countries, from a strictly macroeconomic standpoint, would have been fiscal contraction. ${ }^{11}$ Capital inflows encourage domestic spending, most obviously on interest-rate sensitive activities like construction. A more austere fiscal policy would have damped down this spending response. It would have limited upward pressure on asset prices due to

\footnotetext{
${ }^{8}$ See Mayer and Chatterji (1985) and Archibald and Feldman (1998).

${ }^{9}$ In addition, by using inflammatory language and hanging his own delegation out to dry, FDR signaled clearly that diplomatic and political niceties would not be allowed to take priority over reflationary policies. Thus, it can be argued that the "bombshell message" was an important part of the process of establishing the president's commitment to the new monetary regime.

${ }^{10}$ Recall how China’s growth rate approached 11 per cent in 2010.

${ }^{11}$ I discuss the efficacy, costs and benefits of alternative approaches to managing capital inflows in Eichengreen (2011).
} 
capital inflows. ${ }^{12}$ It would have worked to counter inflationary pressure. By putting downward pressure on local interest rates and narrowing the differential vis-à-vis interest rates in the advanced countries, it would have dampened capital inflows. By limiting both the demand for domestic goods and financial inflows, it would have limited the upward pressure on currencies of which exporters complained.

But here, as in the 1930s, a combination of historical, ideological and political factors prevented governments from responding in first-best fashion. Political consensus on cutting public expenditures in boom times is hard to reach. Political consensus on raising taxes is hard to fashion in both boom times and others. In practice, very substantial fiscal adjustments, as would have been required of small countries seeking to offset large capital inflows, were not politically feasible. Even Chile, a country whose politics and institutions were exceptionally conducive to such adjustments, was not able to use fiscal policy with sufficient flexibility to offset fully the impact of advanced-country policies. ${ }^{13}$

In principle, a superior outcome could have been attained through international coordination. Somewhat less quantitative easing by advanced-country central banks together with somewhat less fiscal tightening by emerging market governments, relative to the first-best unilateral responses, would have produced superior results for both parties. Advanced-country producers would have seen the same increase in demand for their products, the only difference being that more of it would have come from emerging markets. Emerging markets would have seen the same diminution of troublesome capital inflows, what with advanced-country central banks engaging in less quantitative easing, and emergingmarket governments would have been able to avoid the political costs of even larger fiscal adjustments.

In practice, however, international policy coordination to achieve the first-best global optimum was not possible because first-best policies, which would have still involved infeasibly large fiscal adjustments by emerging markets, were not on the table. This situation was thus analogous to the failure of international policy coordination in the 1930s, when the optimal responses were ruled out for political reasons.

Instead, emerging markets responded with second-best measures, as in the 1930s. These were designed to limit capital inflows and/or moderate their domestic impact. Many of these were of limited efficacy or had undesirable side-effects. Trade restrictions designed to aid domestic producers finding it difficult to cope with an appreciated exchange rate posed risks to the global trading system, as in the 1930s (Evenett 2012). Tighter prudential regulation designed to limit the ability of banks to on-lend foreign deposits was offset in part by the diversion of foreign funds into nonbank channels. Cuts in domestic interest rates designed to reduce foreign inflows caused confusion regarding the objectives of monetary policy and did nothing to damp down inflation - quite the contrary. Intervention in the foreign exchange market to limit currency appreciation was either of limited effectiveness if sterilized or liable to have the same undesirable inflationary effects as interest-rate cuts if unsterilized.

The most controversial such measures, again as in the 1930s, were capital controls. In contrast to the 'thirties, many of these controls were price-based rather than administrative; that is, they took the form of taxes on securities purchases by foreigners rather than outright prohibitions. There was nevertheless considerable criticism of controls for creating compliance costs. Their efficacy continues to be debated. Baumann and Gallagher's (2012) analysis of the Brazilian case suggests that controls did more to shift the composition of inflows toward longer-term investments than to change their overall

\footnotetext{
${ }^{12}$ Chin, Filardo, He and Zhu (2011) report evidence that quantitative easing in the United States led to significantly higher equity prices and lower bond spreads in emerging markets. Fratzscher, Lo Duca and Straub (2012) generalize the point. IMF (2011) uses event studies to show that the first round of quantitative easing in the U.S. had significant effects on emerging market currencies and asset prices.

${ }^{13}$ See Velasco (2011) and Frankel (2012) on Chilean politics and institutions, Baumann and Gallagher (2012) on the experience with capital inflows in 2011.
} 
volume. Forbes, Fratzscher, Kostka and Straub (2012), on the other hand, consider Brazilian controls over a longer period and conclude that they did have some effect in moderating the overall volume of inflows. But they also had costs: by raising questions about the authorities' commitment to openness, they may have discouraged desirable forms of foreign investment, direct investment for example. Klein (2012) for his part concludes that controls were more effective in stemming inflows when imposed by countries with less developed financial markets, where opportunities for evasion are fewer, and where controls were of long-standing, since countries with long-standing controls are likely to have incurred the sunk costs required to establish an effective surveillance, reporting and enforcement infrastructure.

There is also a prima facie case for international coordination of these measures. Capital controls, like other macroprudential and macroeconomic policies, can have spillover effects that, in the absence of adequate international coordination, national policy makers will fail to take into account. An obstacle to coordination is that there is no consensus on the magnitude and even the direction of the spillovers. Ostry, Ghosh and Korinek (2012) emphasize the danger of capital-flow diversion - that the imposition of inflow controls by one country may increase the inflows experienced by other countries. But Forbes et al. also find evidence of emulation effects - that the imposition of controls by one country reduces inflows to other countries thought likely to follow its example by making foreign funds harder both to get in and to get out. Spillovers in the two cases operate in opposite directions, with different implications for international coordination. Absent better evidence and more consensus on the sign and magnitude of the spillover effects, the kind of multilateral framework for the use of capital controls envisaged by the International Monetary Fund (IMF 2012) will prove difficult to erect.

\section{Conclusion}

Currency wars, the allegedly beggar-thy-neighbor policies undertaken by central banks of depressed economies, are widely criticized for worsening the world's economic problems in both the 1930s and today. Better, it is argued, would have been for policy authorities in troubled economies to refrain from measures that simply shifted problems onto neighboring countries and instead to have coordinated their responses. The same implications are drawn from both experiences. Indeed, the history of the 1930s is widely invoked by those warning of the dangers of modern-day currency wars.

The analysis here suggests that the history is more nuanced and that more care should be taken in carrying over the lessons of the 1930s to today. In the 1930s, when the countries concerned all experienced an essentially symmetric deflationary shock, what are now referred to as currency wars were part of the solution, not part of the problem. Reflationary policies were needed all around. Under the institutional circumstances of the time, these were achieved by depreciating currencies against gold and hence against the currencies of other countries still on the gold standard. By the second half of the 1930s, global reflation was underway as a result of what was essentially a full round of these so-called beggarthy-neighbor exchange rate changes and the policy initiatives they made possible. International coordination of these increases in the domestic price of gold would have been better to the extent that it limited uncertainty and international recrimination. Whether the difference would have been large or small is an open question. More concentration on the first-best monetary measures appropriate for countering deflation and less recourse to second-best interventions such as trade and capital controls would have been better still. But binding political, ideological and historical constraints prevented some countries from resorting to first-best measures. That in turn made effective international coordination impossible to achieve.

In the recent episode, when the U.S., the Eurozone, the United Kingdom and Japan once again all experienced broadly similar deflationary pressures, quantitative easing bringing about some currency depreciation was again an appropriate symmetrical response. More focus on first-best monetary measures would again have been better, and international coordination of monetary easing might again have 
reduced uncertainty, although how much difference this would have made is, once more, an open question.

The difference in the recent episode is the presence of a second group of economies that were not affected symmetrically. Emerging markets were worried about inflation rather than deflation and about currencies, asset prices and, in some cases, growth rates that were too strong rather than too weak. Their first-best response was fiscal tightening. International coordination of monetary easing in the advanced countries with fiscal tightening in emerging markets would have been better, although once again how much better is a matter for debate. More concentration on first-best fiscal measures appropriate for countering over-strong demand, overheated growth, overvalued currencies and inflation and less recourse to second-best interventions like trade and capital controls, this time too, would have been better still. But once again binding political constraints prevented full recourse to first best measures. And once again they made effective international coordination impossible to achieve. 


\section{References}

Archibald, Robert and David Feldman (1998), "Investment during the Great Depression: Uncertainty and the Role of Smoot Hawley,” Southern Economic Journal 64, pp.857-879.

Baumann, Brittany and Kevin Gallagher (2012), “Navigating Capital Flows in Brazil and Chile,” Initiative for Policy Dialogue Working Paper Series, Tufts University (June).

Bhagwati, Jagdish and V.K. Ramaswami (1963), "Domestic Distortions, Tariffs and the Theory of the Optimal Subsidy,” Journal of Political Economy 71, pp.44-50.

Chen, Qianying, Andrew Filardo, Dong He and Feng Zhu (2011), "International Spillovers of Central Bank Balance Sheet Policies,” unpublished manuscript, Bank for International Settlements (November).

Cooper, Richard (1984), “Economic Interdependence and the Coordination of Economic Policies,” in Peter Kenen (ed.), Handbook of International Economics, Amsterdam: North Holland, pp.1195-1234.

Corsetti, Giancarlo and Paulo Pesenti (2001), “Welfare and Macroeconomic Independence,” Quarterly Journal of Economics 116, pp.421-445.

Eichengreen, Barry (2011), “Managing Capital Inflows,” in Ejaz Ghani (ed.), Reshaping Tomorrow: Is South Asia Ready for the Big Leap? New York: Oxford University Press, pp.202-236.

Eichengreen, Barry and Jeffrey Sachs (1985), "Exchange Rates and Economic Recovery in the 1930s,” Journal of Economy History 49, pp.924-946.

Eichengreen, Barry and Jeffrey Sachs (1986), "Competitive Devaluation and the Great Depression: A Theoretical Reassessment,” Economics Letters 22, pp.67-72.

Eichengreen, Barry and Douglas Irwin (2010), “The Slide to Protectionism in the Great Depression: Who Succumbed and Why?” Journal of Economic History 70, pp.871-897.

Eggertsson, Gauti (2008), “Great Expectations and the End of the Depression,” American Economic Review 98, pp.1476-1516.

Evenett, Simon, ed. (2012), Debacle: The $11^{\text {th }}$ Global Trade Alert Report on

Protectionism, http://www.globaltradealert.org/sites/default/files/GTA11_exec_summary.pdf .

Forbes, Fratzscher, Kostka and Straub (2012), "Bubble Thy Neighbor: Direct and Spillover Effects of Capital Controls,” NBER Working Paper no. 18052 (May).

Frankel, Jeffrey (2012), “Chile’s Countercyclical Triumph,” Foreign Policy On Line (27 June), http://www.foreignpolicy.com/articles/2012/06/27/chile_s_countercyclical_triumph .

Fratzscher, Marcel, Marco Lo Duca and Roland Straub (2012), “A Global Monetary Tsunami? On the Spillovers of US Quantitative Easing,” unpublished manuscript, European Central Bank (November).

Fujiwara, Ippei, Nao Sudo and Yuki Teranishi (2010), "The Zero Lower Bound and Monetary Policy in a Global Economy: A Simple Analytical Investigation,” International Journal of Central Banking 6, pp.103-134.

Gagnon, Joseph, Mathew Raskin, Julie Remache, and Brian Sack (2011), "The Financial Market Effects of the Federal Reserve's Large-Scale Asset Purchases," International Journal of Central Banking 7, pp. 343. 
Haberis, Alex and Anna Lipinska (2012), “International Policy Spillovers at the Zero Lower Bound,” Finance and Economics Discussion Paper no. 2012-23, Washington, D.C.: Board of Governors of the Federal Reserve System.

Howson, Susan (1975), Domestic Monetary Management in Britain 1919-38, Cambridge: Cambridge University Press.

Hamada, Koichi (1976), “A Strategic Analysis of Monetary Interdependence,” Journal of Political Economy 84, pp.677-700.

International Monetary Fund (2011), 2011 Spillover Report, Washington, D.C.: IMF (July).

International Monetary Fund (2012), “The Liberalization and Management of Capital Flows: An Institutional View,” Washington, D.C.: IMF (14 November).

Kapetanios, George, Haroon Mumtaz, Ibrahim Stevens, and Konstantinos Tehodoridis (2012), “Assessing the Economy-wide Effects of Quantitative Easing,” Economic Journal 122, pp.F316-F347.

Klein, Michael (2012), “Capital Controls: Gates and Walls,” Conference draft presented at the Fall 2012 Brookings Panel on Economic Activity, 13-14 September.

Mayer, Thomas and Monojit Chatterji (1985), "Political Shocks and Investment: Some Evidence from the 1930s,” Journal of Economic History 45, pp.913-924.

Meyer, Laurence, Brian Doyle, Joseph Gagnon and Dale Henderson (2002), “International Coordination of Macroeconomic Policies: Still Alive in the New Millennium?” International Finance Discussion Paper no. 723, Washington, D.C.: Board of Governors of the Federal Reserve System (April).

Nevin, Edwin (1955), The Mechanism of Cheap Money, Cardiff: University of Wales Press.

Ostry, Jonathan, Atish Ghosh and Anton Korinek (2012), "Multilateral Aspects of Managing the Capital Account,” IMF Staff Discussion Note (September).

Romer, Christina (1992), “What Ended the Great Depression?” Journal of Economic History 52, pp.757784.

Temin, Peter and Barrie Wigmore (1990), “The End of One Big Deflation,” Explorations in Economic History 27, pp.483-502.

Svensson, Lars (2003), "Escaping from a Liquidity Trap and Deflation: The Foolproof Way and Others,” Journal of Economic Perspectives 17, pp.145-166.

Swanson, Eric T. (2011), "Let's Twist Again: A High-Frequency Event-Study Analysis of Operation Twist and Its Implications for QE2," Brookings Papers on Economic Activity, Spring, pp. 151-88.

Velasco, Andres, “The Fiscal Framework: Lessons from Chile,” Henry Grattan Lecture, Trinity College Dublin, 14 March. 